\title{
Strategies for Sustainability of Environmental \& Resources Efficiency
}

\author{
Joshua Ioji Konov \\ Economic Philosopher \& Management Consultant \\ Chicago IL, the USA.
}

OScholedge International Journal of Multidisciplinary \& Allied Studies (ISSN 2394-336X), Vol.02, Issue 12 (2015) pp1-18. Published by: Scholedge R\&D Center [www.theSCHOLEDGE.org] [Email: sijmas@scholedge.org]

\begin{abstract}
The best global model for expanding Alternative Energies and Environmental Protection is through using market equilibrium, whereas governmental subsidies and fiscal stimulus to be just supplementary. Accelerated Globalization and rising Productivity' Market equilibrium depends on matching consumption demand and supply through price deleveraging. Hence is achievable in a more fair market competition only by changing market (i.e. economic) agents: from presently used trickle-down economics that stimulate big business and big investors to a more market related economics (Marketism) that would stimulate Small \& Medium Businesses and Investors (SME\&I) boost business activities and related employment, fiscal reserves and over all market utilized consumption.
\end{abstract}

\section{Introduction}

Longer-term market development strategies for environmental protection and the adoption of environmentally friendly energy generation and alternative ways of consumption to reduce pollution and waste are essential. Such strategies should be done on a global scale too, whereas the interdependence is real. Shocks apparently emanating in the United States have led to the largest global slowdown since the 1930 .

In general, the alternative energies' technologies and environmental protection are expensive prepositions unreachable by less-developed markets (i.e. economies). While market (i.e. economic) stagnation has been accelerated by the last 2007-9 Great Recession the probabilities for many greatly underdeveloped markets to adapt some advance technologies for environmental protection and reduce pollution and wasting recourses are 
practically incomprehensible. The ongoing globalization and rising productivity have established some very new market (i.e. economic) conditions of deindustrialization of some developed markets as the US, most EU, and Japan ones, and conditions of lack of possibility for industrialization of other undeveloped markets as Eastern Europe, Southern Europe, many African and e.g. markets. "This climb is a permanent, irreversible change. With China and India -- which together account for almost 40 percent of the world's population -resolutely moving up this ladder, structural economic changes in emerging countries will only have more impact on the rest of the world in the future."

The long-term recessions could hardly be self-adjusting by cyclical market forces as it was observed in the last recession this is why the governments intervened in the markets (i.e. economies) through stimulus packages, equity acquisition in the AIG and GM cases, or even farther through Quantitative Easing. Hence, market equilibrium was not left on its selfadjusting powers but it was reached by direct governmental actions to ensure the overall market stability.

The trickle-down economics considers self-adjusting business cycles as necessities for cutting redundancies; a system of market forces based on rising productivity and investment of shady business practices and reduced business laws of tricked-up concentration of capital promoting large transnational corporations and large investors. Capital that would trickledown to markets (e.g. economies); these agents are supposed to prompt and maintain market (i.e. economic) development (i.e. growth). A system that had brought economic growth for a few Centuries in the US, many EU markets (i.e. countries) and Japan the successfully built developed markets (i.e. economies). However, with the most recent accelerated Globalization, rising Productivity, China's industrialization, the overall advances in technologies and Internet the global market equilibrium has been greatly affected*. Hence, the marginalizing US income and declining middle class and "Transnational Corporations, which are considered by the modern economics as frontiers of high productivity and global growth, however their actions have had negative effect in many occasions on the market development of countries as Bulgaria, Romania, Latvia, etc., countries losing equity by letting existing infrastructure deteriorate, reducing their Social Policies and Medicare, and finally deepening into general disproportioned inequality and weak consumption (market demand) into national debt.; 
For the last 20 years and the last 2007-9 Recession's severity was the best example for the imbalance (i.e. disequilibrium) in the local and global "demand-to-supply" marketplaces. The Imbalance (i.e. disequilibrium), which could not have been adjusted but by direct governmental interference and when under the emerging conditions in the European Union interference was not properly applied the consequences were recessionary well observed (e.g. the EU marketplace). Modern days global monetary and fiscal policies by the MDIE that have changes after 1979 from PMAF to AMPF policies. A large deleveraging of foreign assets by Belgium and Swiss banks (about 30 percent of foreign assets), followed by British and German banks (with deleveraging of respectively 24 percent and 21 percent), US and Dutch banks (13 percent), and French banks (10 percent, however the up to 40 deleveraging by all factors of banking can cause high losses and a collapse of international banking activities."

The faster action by the Chinese, the Japanese and the US governments' the better results were observed, the slower and indecisive action by the EU the worst and less successful market (i.e. economic) results. Most studies reach the broad conclusion that fiscal policy is cyclical in developing markets and countercyclical or acyclical in industrialized ones,

Long-term strategies to protect the environment directly reflect a consistent global market development. Hence, pricy technologies for reducing pollution and deforestation could be achieved under the most recent global market conditions only by business diversification, business enhancement, and overall development in a more secure marketplace. The Rule of Law of contract laws, intellectual protection laws, adequate insurance and bonding, etc raises the market security establishing conditions for more lend-able SME\&I and lessdeveloped markets, which combined with the artificial for the markets Social and Environmental Expenses becoming more equitable in such more secure marketplace might invoke major market noise. In Maslov the theory of complexity in monetary policies, which could be achieved by diversity in currencies in this paper is extended to micro-macro market complexity of putting new weights on business from easy business of shady practices into more regulated business. The new complexity (entropy) on a global scale from micro-macro market level will bring similar effect to the real marketplace (i.e. Economy), thus the complexity needed will stop the coming debt disaster and reveres it under the new conditions into global development. 
This paper adopts the necessary technologies and approaches to prevent global worming and exhaustion of resources into a system of relative market equilibrium under the conditions of global market long-term development. However, to succeed such substantial and fundamental change of approaches toward less developed markets is needed, whereas from general market (i.e. economic, business approaches) that promote big business and big investors into one that does promote and maintain relatively fair market competition.

The Marketism is based on free entrepreneurship as the motor for market development (i.e. economic growth). Moreover, the Social and Infrastructural expenses alone with Lower Interest Loans and Subsidies are included as market agents to prompt market development, however artificial to the markets agents that to be used only in cohesion with the natural for the markets free business market agents. The Marketism accepts randomness as market (i.e. business) development (i.e. cycles) whereas the market tools coming out of the market agents (i.e. economic agents) are used to succeed market equilibrium. The accumulated in time market redundancies under this new system of Marketism should be extinguished and deleveraged by using thus natural and artificial market agents, whereas parameters in more like system resembling Quantum Physics called Quantum Economics.

\section{Marketism and Environmental Strategies}

Market development (i.e. economic growth) not relying on the governments but mostly on the free entrepreneurship in the conditions of Global Worming and Decreasing Earth Recourses could be only achieved if global market security is enhanced that is in the fundamentals of the Marketism, whereas Environmental Strategies are not anymore uncompetitive redundancies but part of the market entropy. The Capitalism is based on lower economic security, relatively high lending interest rate (exclude Tier I), shady business practices, Currently, these standards do not create binding legal obligations on U.S. corporations and state law fiduciary duty standards do not compel corporate Boards of Directors to act in furtherance of sharply fluctuating business cycles, etc the Marketism is based on higher market security, relatively lower lending rates, the rule of law in business, adjusted randomly market fluctuations by using statistics to locate and parameters to disperse negative builtups. The formal firms are the most severely affected by financing obstacles. The 
Environmental Strategies could become part of the Marketism in a more diverse business entropy being redundant under the Capitalism as uncompetitive. Under the Capitalism, the Environmental Strategies could be developed through governmental subsidies and fiscal breaks only.

\section{Market Security}

The productivity and the investment are the agents for economic growth in the Capitalism: business laws and regulations, taxation to the rich, social and infrastructural expenses, consumer protection laws, even intellectual property laws, and the environmental and consumer protection laws, e.g. are breaks in the way to economic growth. However, in time, under the social and market pressures the business laws and intellectual protection laws have been better implemented by the best-developed economies than by the developing and undeveloped economies. The developing and undeveloped economies are pressured by the International Organizations (WTO, the WB, and the IMF) toward lower taxation, relaxed business laws and regulations to attract foreign investment "IMF-supported market reforms, with their emphasis on fiscal reforms, have affected the procyclical behavior of government spending in developing countries.". and thus to boost productivity. Pro big business has been considered the only way for global economic growth, therefore some time fraudulent corporate actions have been overlooked. "Corporations may have assets and liabilities, but they don't commit crimes - their officers, executives and employees do. And the 23-page letter agreement between Tyson and the Department of Justice, the criminal information, and the S.E.C.'s public statement of facts all withheld names, identifying the participants only as "senior executive," "VP International," "VP Audit" and so on." generally and 151-153 the transnational corporations : "a large fraction of disputes related to foreign investments nowadays is settled by private arbitration and not by national courts. So corporate law firms and accounting firms add yet additional layers to routine transnational rulemaking." In history such approach had worked fine until the major changes in the last 20-25 years, whereas the major tip-off in industrial production has occurred with the mentioned above* The out of balance system brings the necessities for the Marketism becoming achievable as never before in history. The priority of this new system is to improve the market security establishing the conditions for lower lending rates, and to boost SME\&I and 
Less Developed Countries' market participation. On regional markets or on the global marketplace the effect of improving the market security is to lower interest lending rates that will allow more participants, more business entropy and more consumption (i.e. market demand). By its nature, such change is a market revolution; however, in details it is a very practical micro and macro economic modification of simplified close to the market forces amendments. Achieved high market security would allow long-term environmental strategies' market related utilization, for these becoming part of the global market competition.

\section{Market Changes and Enhancements}

The market (i.e. economic) agents that work to prompt economic growth (i.e. market development) of the Capitalism do not necessary prompt market development (i.e. economic growth) of the Marketism:

\begin{tabular}{|l|l|}
\hline Capitalism & Marketism \\
\hline Shady business contract laws & Strict rule of law in business \\
\hline Limited liability corporate legal form & $\begin{array}{l}\text { Unlimited liability corporate legal for } \\
\text { decision makers form }\end{array}$ \\
\hline Business and market exchanges regulations & Business and market exchanges laws \\
\hline Vague liability and project insurance & $\begin{array}{l}\text { Comprehensive liability and project } \\
\text { insurance, and bonding }\end{array}$ \\
\hline Vague intellectual property protection & Comprehensive intellectual property \\
\hline protection & protection \\
\hline \multicolumn{1}{|c|}{ anvial and infrastructure as expenses } & Social and infrastructure as partial equities \\
\hline
\end{tabular}




\begin{tabular}{|c|c|}
\hline WB and IMF as lender & WB and IMF as promoter and controller \\
\hline Pro cyclical economics & Counter-cyclical economics \\
\hline $\begin{array}{l}\text { Low Governmental employment and lov } \\
\text { taxes }\end{array}$ & $\begin{array}{l}\text { Balanced governmental employment and } \\
\text { taxes to overall market activity }\end{array}$ \\
\hline $\begin{array}{l}\text { Productivity and investment as mai } \\
\text { economic agent }\end{array}$ & $\begin{array}{l}\text { Business entropy (i.e. noise) and diversity as } \\
\text { main market agent }\end{array}$ \\
\hline $\begin{array}{l}\text { National budget as leading indicator to } \\
\text { country's economy }\end{array}$ & $\begin{array}{l}\text { Inflation/deflation as leading indicator to a } \\
\text { country's market }\end{array}$ \\
\hline $\begin{array}{l}\text { Big business and investors as beneficiaries } \\
\text { compare to SME\&I same for small an } \\
\text { underdeveloped countries }\end{array}$ & $\begin{array}{l}\text { All market participants including Small and } \\
\text { Medium business and investors, small and } \\
\text { underdeveloped markets as beneficiaries }\end{array}$ \\
\hline Pro supply economic policies & Pro market equilibrium market economics \\
\hline Global currencies merging (i.e. EU) & Global currencies entropy \\
\hline
\end{tabular}

The Marketism utilizes on these changes and enhancements to marginalize engraved for centuries market insufficiencies in order to accelerate market activities and overall market entropy under a market environment of well developed global industrial basis and capabilities of the US, Japan, China, Germany, and etc.

\section{Environmental Protection one of the Agents for Development}

If higher market security enhances market entropy (i.e. business activities) and diversity the particular and important market agent - Environmental Protection is to be fundamental to carryon even further this market entropy and the following market development. Markets, which are creating conditions for faster market development and could be pushed by targeted market leaps or consistent pressures on some particular market segments that could bring overall accelerated market development. Alternative energies, farming, and 
technologies are the one to improve environmental protection, lower pollution and reduce the usage of Earth resources; however, if these are competitive market activities, boosted through subsidies and low rates lending it (the environmental protection) could be the major agent for overall market development. The most important, as mentioned above, is such market agent to be natural to the market competition (not artificial as it is now, because of the uncompetitiveness of high prices, low productivity, ineffectiveness it brings). Thus, if the system of economics creates more diverse and comprehensive market conditions the entropy (i.e. noise) of such market environment would utilize the Environmental Protection as market more efficient agent. By itself, such market efficiency would create employment and working competitiveness being rightly subjective to current market equilibrium. Whereas improving productivity and international investment is a market agent that increase market entropy by its improving efficiency and competitiveness in an market environment of dominance for Large Businesses and Investors, the improving productivity and international investment enhanced by inclusion of more participants is a market agent to increase the market entropy in a market place overloaded with industrial goods and manufacturing capabilities in a market entropy of no oligopolies (i.e. dominance) but relatively fair market competition.

In a market place with high entropy of business activities the overcapitalization, which in case provoked the 2007-9 Recession would not do such harmful effect because the energies that built such overcapitalization would disperse into other market sections, however preventive actions should be used, too. The transmissionability of a more diverse and active marketplace is to be increasing, therefore any monetary and fiscal actions would have more and faster effect on the overall market (i.e. economy). Generally, under the conditions of lower lending interest rates the market as a whole would be able to accumulate and go through longer-term negative recessionary periods without structural disintegration.

\section{Environmental Protection and Lower Lending Rates}

Lower lending rates mean generally higher business activities, on a global scale consequencual of less poverty and underdevelopment. For the environmental protection to become globally effective an global market prospective is feasible only. Pollution from 
exhausted aging vehicles and primitive heating, deforestation, uncontrollable waste disposal, e.g. are uncontrollable in underdeveloped and undeveloped markets (i.e. countries,

economies), but international dependence from pollution is enveloping Earth. Moreover, if hypothetically the global marketplace driven by productivity and international investment noise is industrialized, and global economic growth is succeeded by the currently accepted economics the disproportioned pollution and exhaustion of resources would destroy it all. If, however, the underdevelopment continues the pollution and waste would destroy it too, maybe a bit later.

Considering these two possibilities only a third, more comprehensive is possible whereas many markets (i.e. economies, countries) are given conditions to develop but not by industrialization. I.e., immediately, the question appears, is it possible, anyway?

\section{Industrialization and Market Development}

The industrialization is the highest point of development in the Capitalism; the technologies and R\&D, education and middle class, taxation and fiscal policies are all directly related to the industrial production, therefore with the decline in industrial production overall economic decline is imminent.

Historically, the farming was fundamental for the economy agent the industrial production is the agent now. However, the new global developments* have reduced the opportunities for many markets (i.e. economies) to maintain needed for their fiscal reserves industrial production and for great many others to industrialize. Thus, developed and developing markets alike could not manage their fiscal balance or develop in case, therefore high unemployment, underemployment, fiscal shortages, declining middle class, deficit and national debt have become synonyms of lack of industrial production. While the Economic Growth was not possible but by industrial production; Market Development is only partially dependent on industrial production. Even productivity and investment agent does not lose importance in Marketism the market entropy from enhanced business activities should become market agent prompting market development, too; the market equilibrium in such conditions should be more market oriented than it is now, whereas governmental involvement would be less in percentage-wise in compression. The improving technologies, 
the internet, the high manufacturing capacity of transnationals and China, the easy moving and outsourcing capabilities, the open global marketplace, e.g. are of great balancing supply market agent.

\section{International Financial Institutions and the Environmental Protection}

The international financial institutions (WTO, WB, and IMF) are being founded on the principle of lending and bank controlling: lending on relatively high interest rate and short term to less and undeveloped markets (i.e. countries). The high risk of the borrowers justified the high rates and short terms. Progressively global security exchange markets have extended their share by trading sovereign debt on free market principles. Both ways, at and after the 2007-9 Recession the abilities of many countries to repay their debt have been declining and fewer countries were daring to borrow from the international financial institutions changing them to transmitters of subsidies and emergencies help funds. While public flows plunged in all countries, there is an indication that grants were replacing loans in low-income countries, which is consistent with donor commitments. The targeted by the international financial institutions global economic growth has decelerated into global slow down or recession but a few exceptions. This process, however, has had some longer tail of at least 20 years with deteriorating undeveloped markets' borrow-ability and repaymentability, which process could be connected to the weakening consumption in the most developed economies and the rising industrial capability of China, India, and e.g. that has undercut many undeveloped markets (i.e. countries) of manufacturing and exporting goods. As some of these countries are also heavily dependent on external financing from banks and investors, around 60-70 percent for Greece, Ireland and Portugal, a financing crisis becomes almost inevitable. The return on the invested capital coming through WB and IMF funds for many countries has deteriorated, also "The outflow of foreign capital from emerging and developing countries, with its destabilizing effect on private and public finances in these markets". whereas the globalization has utilized energy and commodity prices rising constantly. Hence, the borrowed capital disappeared into covering previous debt, basic expenses, and corruption instead of prompting economic growth. The international financial institutions started lending on project-by-project basis that made no difference to the conclusions above. 
Even the ways of lending of the international financial institutions have practically changed, ideologically and conceptionally they have not evolved: the formal tightening budgets and close deficit observance are in practice as ever. Hence in a volatile and insecure marketplace is well reasonable. However, with the ongoing changes of realities* the role of the international financial institutions must change too by comprehending and accommodating these realities into regulatory and financial structures prompting market development and managing inflationary processes. From mostly being a lender and collector to mostly being a promoter and controller the international financial institutions should promote the rule of low in business and other Marketism' utilities on the global marketplace, and thru lower lending rates to raise market noise and diversity.

\section{Business Laws and Environmental Protection}

Business regulations mostly used for environmental protection should change into business laws apply indiscriminately and unconditionally. Moreover, formal firm growth improves with better enforcement as measured by fair and impartial courts, while informal firm growth is constrained by organized crime, pointing to their inability to take full advantage of the legal and judicial systems. Hence, unless easing business laws in currently used system prompt economics growth the enhanced business laws would have the opposite effect under the Marketism prompting market noise and diverse business environment. When it comes to environmental protection, the effect by such change would have the most positive consequences of all. In a higher security market place in lower lending rates environment whereas governments and international organizations use subsidies and fiscal tools to boost market development through marginalizing market disadvantage for the SME\&I the whole new market opportunities will appear... the individual imagination and creativity and the individual entrepreneurship would flourish. Things like consumer protection and environmental protection, the strict business laws e.g. would not prevent businesses and investors from expanding, but in the opposite will level-up competition creating more opportunities in high technologies and more market related education. 


\section{Conclusions}

This paper may seem too optimistic and bordering unreality, however the possibilities that could come with rising market security on a global scale may go even further. The inclusion of Environmental Protection in the market competition as an market agent instead of the subsidized by the governments artificial part is a possibility, if not the only one that could save Earth from destruction. The system of Marketism is founded on free entrepreneurship and individual freedoms a natural Historical extension entailed into the best-succeeded economic systems of the past.

\section{References}

Acconcia, Antonio, Giancarlo Corsetti and Saverio Simonelly Mafia and Public Spending: Evidence on the Fiscal Multiplier from a Quasi-experiment, WP/281

Alichi, Ali, Huigang Chen, Kevin Clinton, Charles Freedman, Marianne Johnson, Ondra Kamenik, Turgut $\mathrm{Ki}^{\wedge}$ inbay, and Douglas Laxton, Inflation Targeting Under Imperfect Policy Credibility, WP/09/94

Allen, Richard, The Challenge of Reforming Budgetary Institutions in Developing Countries WP/09/96

Anderson, Richard G., Jane M. Binner Vincent A. Schmidt," Describing the Pass-through of Individual Goods Prices into Trend Inflation in the United States, Working Paper 2011

Arslanalp, Serkan, Fabian Bornhorst, Sanjeev Gupta, and Elsa Sze, Public Capital and Growth, WP/10/175

Aruoba, S. Boragan, Francis X. Diebold, M. Ayhan Kose, and Terrones Marco E. "Globalization, the BusinessCycle, and Macroeconomic Monitoring", WP/11/25

Aspachs-Bracons, Oriol and Pau Rabanal, The Effects of Housing Prices and Monetary Policy in a Currency Union, WP/11/6 
Babecky, Jan, Ales Bulir, and Katerina Smidkova, Sustainable Real Exchange Rates in the New EU Member States: What did the Great Recession Change? WP/10/198

Baldacci, Emanuele, Sanjeev Gupta, and Carlos Mulas-Granados, Restoring Debt Sustainability After Crises: Implications for the Fiscal Mix WP//10/232

Bandyopadhyay, Subhayu and Suryadipta Roy "Political Economy Determinants of Nonagricultural Trade Policy “,Federal Reserve Bank of St. Louis Review, March/April 2011

Bastiat, Frederic. Economic Sophisms. Irvington-on-Hudson: Foundation for Economic Education, 1996.

Bayoumi, Tamim and Trung Bui Deconstructing the International Business Cycle: Why does a U.S. sneeze give the rest of the world a cold?, WP/10/239, October 2010

Benes, Jaromir, Kevin Clinton, Marianne Johnson, Douglas Laxton, and Troy Matheson, Models in Real Time1, March 2010

Benes, Jaromir, Michael Kumhof, Risky Bank Lending and Optimal Capital Adequacy Regulation WP/11/130

Bernardin Akitoby, Benedict Clements, Sanjeev Gupta, and Gabriela Inchauste, The Cyclical and Long-Term Behavior of Government Expenditures in Developing Countries, WP/04/202

Brzoza-Brzezina, Michat, Pascal Jacquinot, Marcin Kolasa CAN WE PREVENT BOOM-BUST CYCLES DURING EURO AREA ACCESSION? (WPS 1280) 2010

Chami, Ralph, Dalia Hakura, and Peter Montiel, Remittances: An Automatic Output Stabilizer? WP/og/9

Chan-Lau, Jorge A. and Andre O. Santos, Public Debt Sustainability and Management in a Compound Option Framework, WP/10/2

Choi, Woon Gyu and Yi Wen 1, Dissecting Taylor Rules in a Structural VAR, WP/10/20 
Combes, Jean-Louis, Tidiane Kinda, and Patrick Plane Capital Flows, Exchange Rate Flexibility, and the Real Exchange Rate", WP1109

Contessi, Silvio, What Happens When Wal-Mart Comes to Your Country? Multinational Firms' Entry, Productivity, and Inefficiency, 2010

Crowe, Christopher, Consensus Forecasts and Inefficient Information Aggregation, WP/10/178

Dabla-Norris, Era, Jim Brumby, Annette Kyobe, Zac Mills, and Chris Papageorgiou; Investing in Public Investment: An Index of Public Investment Efficiency, (Straub, 2008)

De Broeck, Mark and Anastasia Guscina, Government Debt Issuance in the Euro Area: The Impact of the Financial Crisis, WP/1121

del Granado, Javier Arze, Sanjeev Gupta, and Alejandro Hajdenberg, Is Social Spending Procyclical?, WP/10/234

Espinoza, Raphael and Abdelhak Senhadji," How Strong are Fiscal Multipliers in the GCC? An Empirical Investigation, 2011

Friedman, Thomas L. The Lexus and the Olive Tree: Understanding Globalization. New York: Anchor Books, 2000

Garcia, Carlos, Jorge E. Restrepo, and Evan Tanner, Fiscal Rules in a Volatile World: A WelfareBased Approach, WP/11/56

Hidalgo, Esteban Guevara EGT through Quantum Mechanics \& from Statistical Physics to Economics (2007)

Ilgmann, Cordelius, The Advent of Corporate Limited Liability in Prussia 1843, Centre of Applied Economic Research Münster, University of Münster, 2011

Kahan, Daniel R., Shareholder Liability for Corporate Torts: A Historical Perspective, Georgetown University, A.B. 2006. ๑ 2009 
Khanna, Ro Entrepreneurial Nation: Why Manufacturing is Still Key to America's Future 2013

Konov, Joshua 1. Ioji / JK, 2011. "2001 \& 2007 Recessions prompted remaking of the international organizations," MPRA Paper 34588, University Library of Munich, Germany.

Konov, Joshua Ioji / JK, 2011. "Piercing the Veil's Effect on Corporate Human Rights Violations \& International Corporate Crime (Human Trafficking, Slavery, etc)," MPRA Paper 35714, University Library of Munich, Germany.

Kumhof, M., D. Laxton, D. Muir and S. Mursula, 2010, "The Global Integrated Monetary Fiscal Model (GIMF) - Theoretical Structure," IMF Working Paper 10/34.

Kumhof, Michael, Douglas Laxton, and Daniel Leigh, To Starve or not to Starve the Beast?, WP/10/199

Law firm of Fried, Frank, Harris, Shriver \& Jacobson LLP, Trends in the Use of Corporate Law and Shareholder Activism to Increase Corporate Responsibility and Accountability for Human Rights1, 2009

Leeper, Eric M., Todd B. Walker, and Shu-Chun S. Yang, Government Investment and Fiscal Stimulus, WP/10/229

Llaudes, Ricardo, Ferhan Salman, and Mali Chivakul, The Impact of the Great Recession on Emerging Markets WP/10/237, 2010

Manasse, Paolo, Procyclical Fiscal Policy: Shocks, Rules, and Institutions-A View From MARS, WP/06/27

Maslov, V.P. Economic law of increase of Kolmogorov complexity. Transition from financial crisis 2008 to the zero-order phase transition (social explosion), 2008

Mrkaic, Mico, Information Content of DQAF Indicators-Empirical Entropy Analysis, $\mathrm{WP} / 10 / 204$

Nabar, Malhar and Murtaza Syed, The Great Rebalancing Act: Can Investment Be a Lever in Asia 
N'Diaye, Papa, Countercyclical Macro Prudential Policies in a Supporting Role to Monetary Policy, WP/09/257

Neely, Christopher J., Assistant Vice President and Economist, Fiscal Policy and Expected Inflation, Economic synopses, short essays and reports on the economic issues of the day 2011, Number 8

Nielsen, Lynge, Relative Poverty Prepared ,WP/09/93

OECD, 2009, "The Effectiveness and Scope of Fiscal Stimulus," OECD Economic Outlook, Chapter 3, pp. 105-150.

Reinhardt, Dennis, Luca Antonio Ricci and Thierry Tressel, International Capital Flows and Development: Financial Openness Matters, WP/10/235

Reinhart, Carmen and Rogoff, Kenneth "Growth in a Time of Debt" (GITD hereafter) 2009

Rudrani Bhattacharya, Ila Patnaik and Ajay Shah "Monetary policy transmission in an emerging market setting", January 2011.

Ruggie, John Gerard International Regimes, Transactions, and Change: Embedded Liberalism in the Postwar Economic Order International Organization, Vol. 36, No. 2, International Regimes (Spring, 1982)

Ruggie, John Gerard State Responsibilities to Regulate and Adjudicate Corporate Activities under the United Nations' core Human Rights (12 February 2007)

Ruggie, John Gerard, 2007 “Business and Human Rights: The Evolving International Agenda." Corporate Social Responsibility Initiative, WP/31

Saez, Emmanuel Striking it Richer: The Evolution of Top Incomes in the United States January 23, 2013

Scandizzo, Stefania, Intellectual Property Rights and International R\&D Competition, $\mathrm{WP} / 01 / 81$ 
Schnaiberg, Allan and Kenneth A. Gould. 1994. Environment and Society: The Enduring Conflict. New York: St. Martin's Press. ISBN: 0312102666

Schnaiberg, Allan.. The Environment: From Surplus to Scarcity. New York: Oxford University Press. ISBN: $019502611 X, 1980$

Sengupta, Rajdeep and Mara Faccio, Corporate Response to Distress: Evidence from the Asian Financial Crisis, Federal Reserve Bank of St. Louis Review, March/April 2011, 93(2), pp. $127-54$

Shultz, George, William Simon and Walter Wriston. "Who Needs the IMF?" Wall Street Journal, February 3, 1998.

Silverberg, Gerald and Bart Verspagen, "An evolutionary model of long term cyclical variations of catching up and falling behind", 1995

Singh, Manmohan and James Aitken, The (sizable) Role of Rehypothecation in the Shadow Banking System, WP/10/172

Smith, Adam. The Wealth of Nations. Modern Library Edition. New York: Random House, 1937.

Stiglitz, Joseph E. Globalization and Its Discontents. New York: W.W. Norton \& Co., 2002.

Sum, Andrew Ishwar Khatiwada Joseph McLaughlin, Sheila Palma The "Jobless and Wageless" Recovery from the Great Recession of 20072009: The Magnitude and Sources of Economic Growth Through 2011 I and Their Impacts on Workers, Profits, and Stock Values", May 2011

The Business Cycle Dating Committee of the National Bureau of Economic Research, the committee determined that a trough in business activity occurred in the U.S. economy in June 2009 the end of the recession, CAMBRIDGE September 20, 2010

Thornton, Daniel L., Vice President and Economic Adviser Monetary Policy at the Zero Bound, Number 7, 2011. 
Traum, Nora and Shu-Chun S. Yang, Monetary and Fiscal Policy Interactions in the Post-war U.S. WP/10/243

Tressel, Thierry, Financial Contagion through Bank Deleveraging: Stylized Facts and Simulations Applied to the Financial Crisis, WP/10/236

Watt, Stanley, Firm Heterogeneity and Weak Intellectual Property Rights, WP/07/161 